\title{
Self-Storage Cities: A New Typology of (Sub)Urban Enclave
}

MARIATERESA AIELLO

NewSchool of Architecture \& Design

In the periphery, arrays of self-storage facilities are part of the light industrial landscape of warehouses and ex-urban alienation. Within the urban fabric, storage buildings represent both container and camouflage architecture, and are perfect examples of what Professor Crawford calls "background buildings." ${ }^{1}$ Self-storage facilities are an architectural typology worthy of study, and not only for their growing impact on the city and suburban sprawl, or for the uncanny ability to mimic other design typologies and adapt to the target market. They can be examined in terms of building type and construction methods. From the economic point of view, storage facilities are compelling: they are a by-product of shopping/ goods architecture, consumerism and planned obsolescence. They embody currently popular issues of surplus and clutter/hoarding. The issue of "material excess" becomes an (ex) urban pathology, endemic to a culture of wholesale commerce and warehouse buying experiences. The clutter culture can be mapped and becomes tangible in the form of the "country of storage facilities", a veritable document to "stuff obesity". The current rise of self-storage facilities is also a physical reminder of the consequence of changes in social and living conditions. How do we, as architects and urban designers, confront the typology of the self-storage facility and the new urban/exurban enclaves that these commercial containers of space have created? How can we better understand the nature of the singularly camouflaged "housing of stuff" often found in the downtowns of second-tier U.S cities? The content of these buildings, the "user" if you wish, is constituted entirely of stuff we cannot or do not wish to fit in our homes. What is it that we store, and why?

\section{SELF STORAGE: DEFINITIONS AND BACKGROUND}

According to Self Storage Economics, self-storage is essentially the concept of storing possessions. ${ }^{2}$ The term 'self-storage' is short for 'self-service storage', also known as 'mini storage'. ${ }^{3}$ The American Heritage Dictionary defines self-storage as a commercial facility in which consumers can rent space or store possessions. Yet, a selfstorage property is much more than just a container for unused possessions: it is a specialized type of property with unique legal characteristics, and an investment business. While many types of structures have been converted from warehouses, car dealerships, and other prior-use buildings, the most common types of facilities were designed specifically for the purpose of storing a customer's goods. ${ }^{4}$ This paper aims to examine the self-storage facility as architectural typology and, on a macro-level, as urban/exurban enclave. Storage facilities are exhibiting an unparalleled growth in recent years: according to the Self Storage Association the self-storage industry has been the fastest growing segment of the commercial real estate industry over the last 40 years. ${ }^{5}$ In 2015, a Wall Street Journal report called it "recession- resistant". ${ }^{6}$ There are approximately 60,000 self-storage facilities worldwide as of 2015, and more than 86 percent (or 50,100) are found in the United States. It took the selfstorage industry more than 25 years to build its first billion square feet of space; it added the second billion square feet in just 8 years (1998-2005). ${ }^{5}$ It presently occupies a total rentable space of 2.2 billion square feet - an area of more than 78 square miles, or 204 square kilometers, of rentable self-storage space. This is equivalent to a surface three times the size of Manhattan, and in continuous growth. There is a total U.S. storage capacity of about $7.3 \mathrm{sq}$. $\mathrm{ft}$. of self-storage space for every man, woman and child in the nation; thus, it is physically possible that every American could stand inside the storage units currently built. ${ }^{5}$ From the economic standpoint, this is an extremely lucrative business: the self-storage industry generated $\$ 27.2$ billion in annual U.S. revenue in 2014. The revenue forecast for 2016 is 32.7 billion. ${ }^{7}$ Globally, there are currently close to 8,000 self-storage facilities: 3000 are found in Canada, ${ }^{5}$ 2,035 in Japan, 1425 in Australia and New Zealand, 815 in the U.K, 882 in the rest of Europe and 200 in South Africa. ${ }^{8}$ In Latin America there are currently 250 facilities and Mexico is leading with 35 operators. ${ }^{9}$ Self-storage facilities are an emergent typology in Singapore and China. 


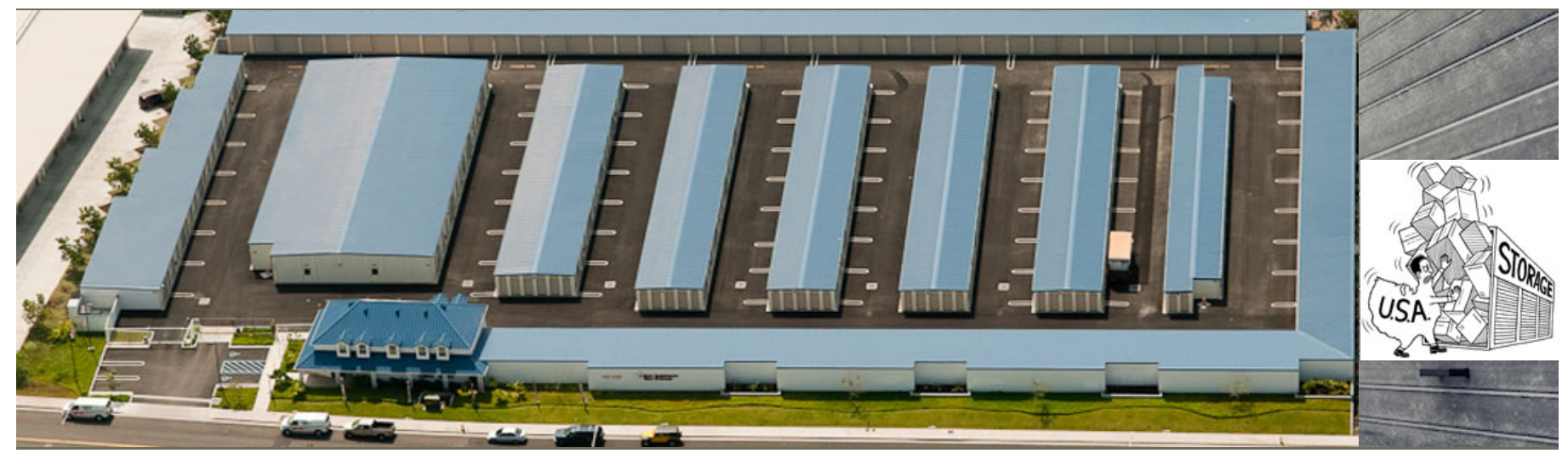

Figure 1: Less Mess Storage Inc. in Canada. US Self Storage. Web. Figure 2: Illustration from "Self-Storage Nation". Slate. Web

\section{A BRIEF HISTORY OF STORAGE}

The history of the storage typology starts with food storage, but it also shares some commonalities with tomb architecture, in the sense that, for millennia, humans have found ways to store the things they cherish. Storage is synonymous with surplus. We need to consider the history of storage as parallel to the development of more and more complex types of societies- and of course as part of the history of dwelling. Recent excavations near Dhra, Jordan, reveal evidence of the world's oldest known granaries, which predate large-scale sedentary communities and agro-pastoralist economies of the Neolithic by at least 1,000 years. They are dated 11,500 to 10,550 B.C.E. ${ }^{14}$ In Xi'an, China 6,000 years ago inhabitants would place their belongingsto-do lists etched in turtle shell, bamboo reed flip-flops, collectible spearheads, and family heirloom jewelry made of jade and teethin clay pots and store them in underground pits. Guards monitored these storage areas to ensure no one removed another person's pot or its contents. ${ }^{16}$

In 19th century England, customers embarking on extended voyages would leave their valuables in care of British banking institutions. The banks would guarantee their customers' valuables in the event of loss, theft or damage. ${ }^{17}$ Overcrowded vaults quickly forced bankers to seek storage in lofts from drayage (moving) companies. ${ }^{4}$ Possessions were packed into crates marked with the owner's name (an early version of lockers or mini-storages) and placed into secure lofts. Watchmen were posted to guard the lofts. ${ }^{17}$ In the 1850 's, the first warehouse specifically constructed for household and personal items was built. This two-story structure was built with packing on the ground floor and private storage rooms on the first. ${ }^{4}$ The history and evolution of warehouses for storage is tied to the history of fire-proof construction: English designers first introduced the iron and brick fireproof system in textile mills and warehouses in the 1790 s. ${ }^{18}$

The first commercially viable storage company in the United States is thought to have been founded in 1889, in Sioux City, lowa by the brothers Martin and John Bekins, the sons of Dutch immigrants. ${ }^{19}$ In 1891, a third Bekins brother founded Bekins Vans \& Storage Company in Omaha, Nebraska. The Bekins Company was the first to move from horse-drawn wagons in moving and storage with the first motor trucks in 1903. Bekins also opened branches in Chicago and then Seattle, where it opened the first furniture storage facility in the Pacific Northwest. ${ }^{20}$ In 1895, the company expanded to California, the site of recent oil discoveries and the terminus of the new transcontinental railway, not to mention enormous population growth. All this meant an extreme fertile ground for the moving and storage business. By 1906 the Bekins Warehouse was built in Los Angeles. It was the first reinforced steel and concrete building in the city. The second Bekins Warehouse was built in San Francisco. It is interesting to note that, during the great earthquake of 1906 in San Francisco this warehouse was one of the few structures that did not collapse. ${ }^{21}$ In the first half of the 20th century, the company set up a large number of fireproof warehouses throughout Southern California. After World War II, Bekins focused in moving and storing for households, military personnel, business and industrial outfits. The Bekins Company pioneered the modern concept of 'containerized' storage. For the next sixty years, the storage industry stayed relatively unchanged. Warehouses began increasing in size to as much as ten stories utilizing freight elevators to reach the storage rooms. The 1920s saw a large number of companies enter the self-storage industry. In 1928, Arthur Trachte, of Trachte Building Systems, built interconnected metal garages for "cars without homes". ${ }^{21}$ Storage facilities for vehicles were being pitched as a way to make vacant lots profitable in an ad by the Trachte company: units could be used to store vehicles, sort of like a pre-cursor to public garages.

During the 1950's, the storage industry was faced with rising cost of warehouses and land. As a result, palletized warehousing was developed. Tenants' goods were crated and stacked three high in wooden boxes moved around with a forklift. While the concept worked well, it was inconvenient and costly to the customer. ${ }^{4}$ According to US Self Storage, the Collum family founded the very first drive-up self-storage facility for residential tenants in Fort Lauderdale, Florida, in 1958. ${ }^{26}$ The first facility which featured garage-style doors was built by Russ Williams in Odessa, Texas, in 1964. It was aptly named A-1 U-Store-It U-Lock-It U-Carry-The-Key. The building serviced the local oil industry and fishermen, so that workers could have quick access to tools and supplies. These early self-storage units were 100 feet by 30 feet, the right dimensions for storing bass boat trailers. ${ }^{16}$ Soon after both models were copied and self-storage facilities began to appear everywhere in the United States. In 1972, the first Public Storage facility 


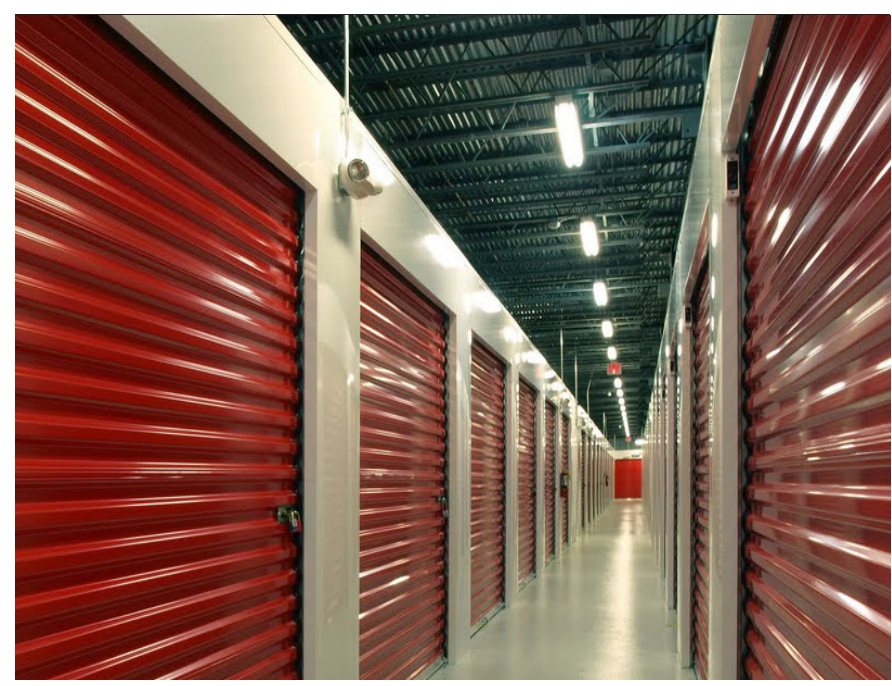

Figure 3: A Self Storage Interior - The Catacombs of Consumerism Interior Standard Storage Units in Washington, PA. Guardian Storage. Web.

opened in El Cajon, California (fittingly, el cajon is Spanish for 'the big box' or 'drawer') and self-storage boomed into a large-scale industry.

\section{THE BUSINESS OF STORING STUFF}

The total market value of self-storage in the U.S. is upward of $\$ 220$ billion. ${ }^{30}$ Nearly 1 -in-10 of U.S. households currently rent a self-storage unit, which has increased from 1-in-17 since 1995. This represents a 65 percent increase in the last 15 years. ${ }^{32}$ Most operators of selfstorage facilities report ninety percent occupancy, with average stints among its renters of 15 months. ${ }^{23}$ Average rents nationally for a $10 \times 10$ storage unit is $\$ 125$ a month, and $\$ 159$ a month if the unit is climate-controlled, according to 2016 statistics from the Self-Storage Association. ${ }^{33}$ The line between real estate and the selfstorage facility industry is becoming more and more blurred. As we learn from US Self Storage, REITs (Real Estate Investment Trusts) are increasingly investing in storage facilities. Self-storage REIT's had higher 2011 returns than any other real estate investment, including healthcare, residential, retail, industrial/office and lodging/resort. ${ }^{34}$ Unfortunately, the benefits of investing in self-storage come to the expenses of customers and communities. Storage facilities employ a negligible number of local residents and do not pay sales taxes. They use tenancy contracts that would make other landlords shudder. ${ }^{38}$ If a customer is in default of payment, storage owners can lock them out of the unit. If they remain in arrear, Steel Storage reminds potential investors that "the ability to quickly remove and replace non-paying tenants is a well-known feature of the industry". They suggest to simply clear the unit, sell its contents and rent it to the next customer. This sometimes predatory practice has made self-storage facilities infamous through American reality television series such as Storage Wars and Auction Hunters.

There are just as many storage facilities in the US as McDonald's, Starbucks and Subway franchises, combined. ${ }^{41}$ Assuming that the industry is 60 years old and based on available growth data, it can be concluded that the industry has grown at an average rate of 834 facilities per year. ${ }^{26}$ US Self Storage claimed in November 2015 that the current record-setting growth does not show any signs of slowing down. ${ }^{36}$ If the current level of consumptions is maintained in U.S., and encouraged in the bourgeoning European, Asian and Australasian markets, facilities will continue to grow. They will even become, in developing countries, a marker of having achieved western affluence like car ownership and pollution.

\section{SELF-STORAGE NATION: WHO STORES WHAT AND WHY}

Self-storage is a surprisingly fertile cultural indicator. ${ }^{23}$ Its tenants fall into four main categories: residential (70.4 percent), commercial (17.1 percent) , student (6.3 percent) and military (6.2 percent). ${ }^{43}$ The majority of self-storage users in the U.S. (65 percent), have an annual combined household income of less than $\$ 75,000$ per year. 37 percent of all self-storage renters have an annual household income of less than $\$ 40,000$ per year. ${ }^{44} 68$ percent of self-storage renters live in a single family household, while 27 percent live in an apartment or condo.

\section{What Are We Storing: Clutter and Guilt}

An article in the satirical publications The Onion calls self-storage units "museums of personal failure" and, in Self-Storage Nation, the author, Tom Vanderbilt, calls self-storage facilities "catacombs of consumerism". The most common items in household storage units are, in order, furniture, photographs, kitchenware, clothing, holiday decorations, household supplies, books and magazines, collectibles and hobby items, tools, and sporting equipment. Furniture is the most commonly thing stored in U.S. In fact, some seven million American households had, in 2009, at least one piece of furniture in storage. Juliet B. Schor, a Boston College sociologist, calls it the "Ikea effect": Americans have spent more on furniture, even as the prices have dropped, therefore amassing more of it. ${ }^{27}$ Although experts estimate just 2 percent to 5 percent ${ }^{47}$ of the U.S. population officially falls into the hoarding category, ${ }^{48}$ according to the research done for Sparefoot, 52 percent of Americans describe their home as cluttered, including 59 percent of millennials. 61 percent of Americans believe moving is the best- and only- opportunity to declutter their home.

Cities that Stuff Built: Why do we need storages?

For many years, storage facilities functioned based on "life events", such as moves, marriages, divorces and deaths. As disposable personal income grew and the cost of goods plunged starting in 1970, storage facilities began a steady growth, holding the overflow of American homes. ${ }^{28}$ The late 20 th century turned out to be a golden age of life events in U.S, with peaking divorce rates and a rush of second- and third-home buying. Storage architecture is a byproduct of shopping/goods architecture: if malls were the pleasure palaces that consumerism built, storage facilities are its landfills. In this cycle of consumption, we are experiencing an interesting phenomenon: as malls become outdated models and turn into modern ruins, abandoned and shuttered, storage facilities are flourishing and sometime assume the gaudy aesthetics of malls. Hayden in a Field Guide to Sprawl connects consumerism to sprawl in stating that visible waste is an inherent part of sprawl, seen in poorly used land, automobile 


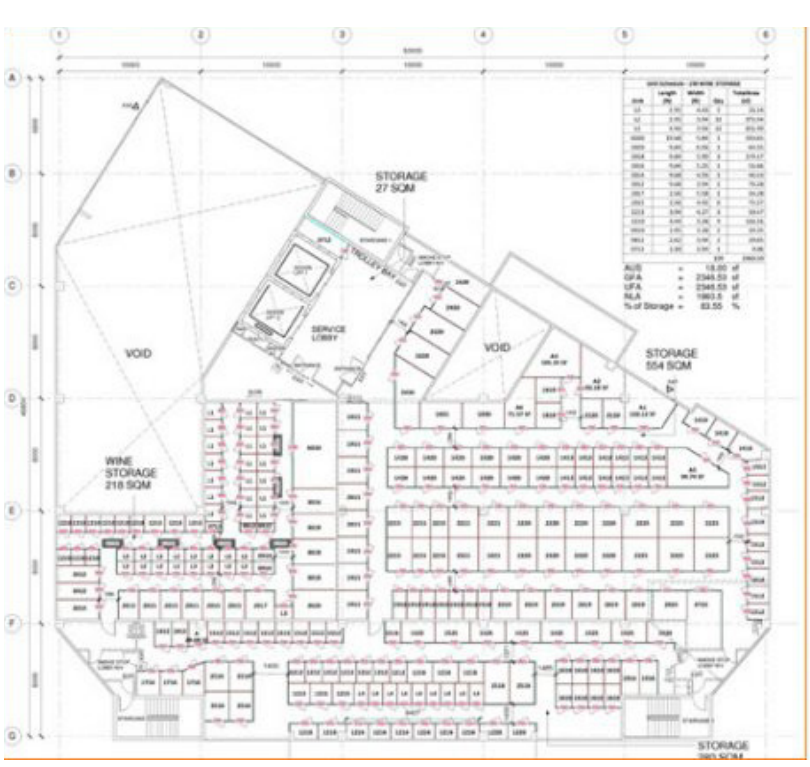

Figure 4: Floor plan and rendering of a self-storage facility with wine storage. Architectural Design. Steel Storage. Web.

junkyards, overflowing landfills, and exported garbage. ${ }^{55}$ The average U.S. person now consumes twice as much as they did 50 years ago. ${ }^{56}$ The average U.S. house size has doubled since the $1970 \mathrm{~s},{ }^{57}$ the average family size got smaller, ${ }^{23}$ yet Americans seem to have an unquenchable thirst for space. The notion of self-storage is aligned with the principle that it's the accumulation of things that defines you as an American and that throwing anything away is wasteful. The selfstorage industry reconciles these opposing values: paying for storage is, paradoxically, thrifty. ${ }^{27}$

\section{SELF STORAGE FACILITY AS AN ARCHITECTURAL TYPOLOGY}

Banished to the outskirts of the city or town, storage facilities are part of a fragmented, placeless blandscape. Storages exist in places that already lack vitality and when they are transplanted in the urban fabric they become urban pathologies. Storage units embody different identities: they have been known to house everything, from bodies to drug operations ${ }^{8}$ and have been converted to places of businesses for both lawyers and prostitutes. Storage facilities, rarely legitimized as architecture, could be included in a discussion on corridor architecture due to their unique layout. They are a prosaic case study for the conversation initiated in essays such as Corridor Spaces by Mark Jarzombek and Robin Evans' analysis of passages. ${ }^{59}$ Storage facilities range from multi-unit single buildings to multi-story 'design' centers. ${ }^{60}$ The first generation of self-storage facilities was little more than a collection of prefab tin garages ${ }^{4}$. The majority of facilities operating today may be classified as "second generation" self-storage. These include: typical row buildings, some multi story facilities and conversion of older buildings. The "third generation" of self-storage is characterized by the following: retail locations, light commercial or even multifamily residential neighborhoods. The first distinction to be made is between portable storage and fixed storage. Portable storage consists in containers stored in-house by a facility or remotely. The containers and their contents are sometimes accessible via a webcam (virtual storage units). The fixed storage is subdivided in the following categories: single story, single story conditioned, multi-story and mechanized. ${ }^{61}$ Storage facilities consist of: drive-up facilities (the preferred mode in North America and Australia), purpose-built facilities (typically a two to three story lightweight steel structure) and building conversion using existing industrial (typically factory or warehouse) or former office spaces. ${ }^{38}$ Storage facilities are mostly built employing the following building systems: beam and purlin, masonry shell and interior metal partition, light gauge construction, masonry shell and steel spanning, and, finally utilizing pre-fab construction. ${ }^{61}$ The architectural design of a storage facility starts with the floor plan or "space mix" design. A space mix is the variety of self-storage unit sizes that make up the layout of the floor plan. ${ }^{62}$ The average unit size varies per country/ region. An ideal team to undertake a self-storage facility project would include a feasibility consultant to define successful parameters , a civil engineer to carry out the site analysis, an architect to maximize the site and develop the project visibility, and finally a general contractor with steel experience to assist in structural design and budgeting. ${ }^{63}$

The exterior of storage facilities ranges from banal to outright garish. When they aim for design, storage facilities tend to acquire, in their exterior and interior, an architecture that mimics the historical, aesthetic or folksy flavor of the surrounding community. City planners will often request that developers blend in with existing community structures. But there are those who are trying to break the mold and make a statement. Miami architect Peter Blitstein despises traditional self-storage design and has reinvented what he calls the "windowless box". His projects, sophisticated mixed-use storage facilities that might pass for cutting-edge corporate headquarters, are found throughout the urban landscape of Miami. ${ }^{64}$

Storage customers and storage use have also become diversified in recent years: storage units have become incubators for small businesses and artisans, warehouses for pharmaceutical reps or landscapers, band practice rooms, man caves, showrooms and even training studios. Storage facilities now have roof decks, lounges and 


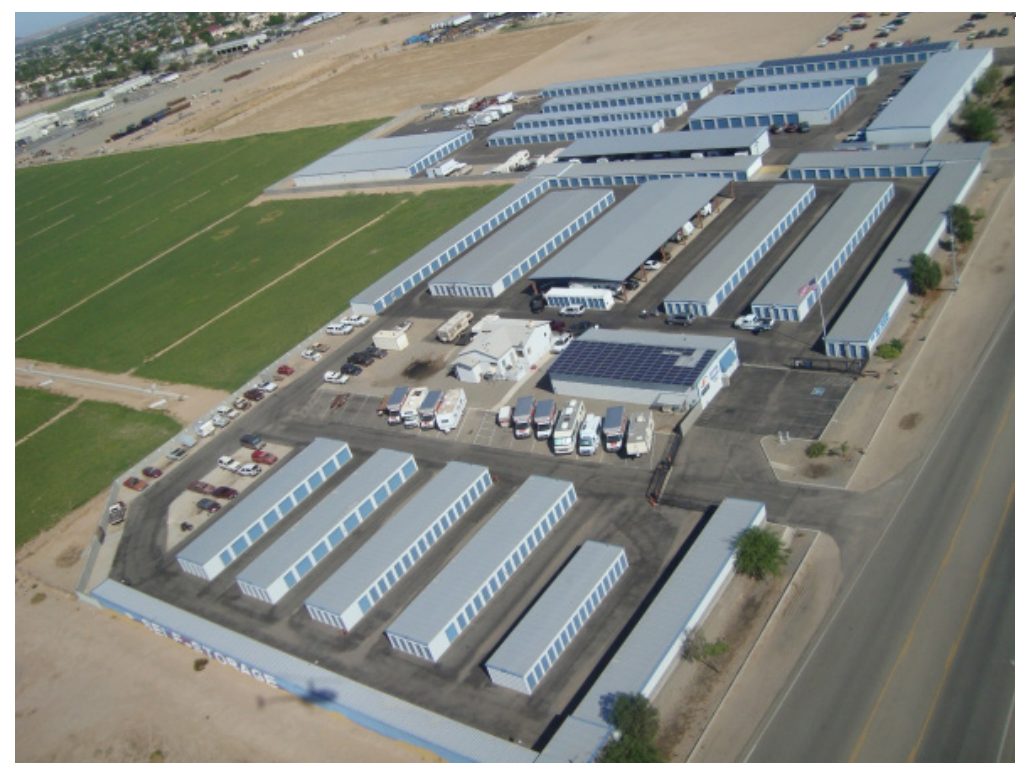

Fixed Storage

Unit Dimensions

Unit Dimensions
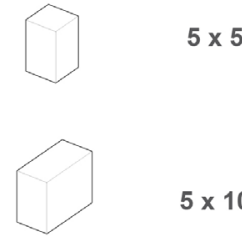

$5 \times 10$

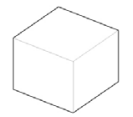

$10 \times 10$

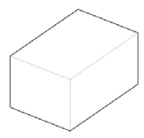

$10 \times 15$

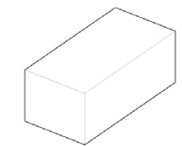

$10 \times 20$
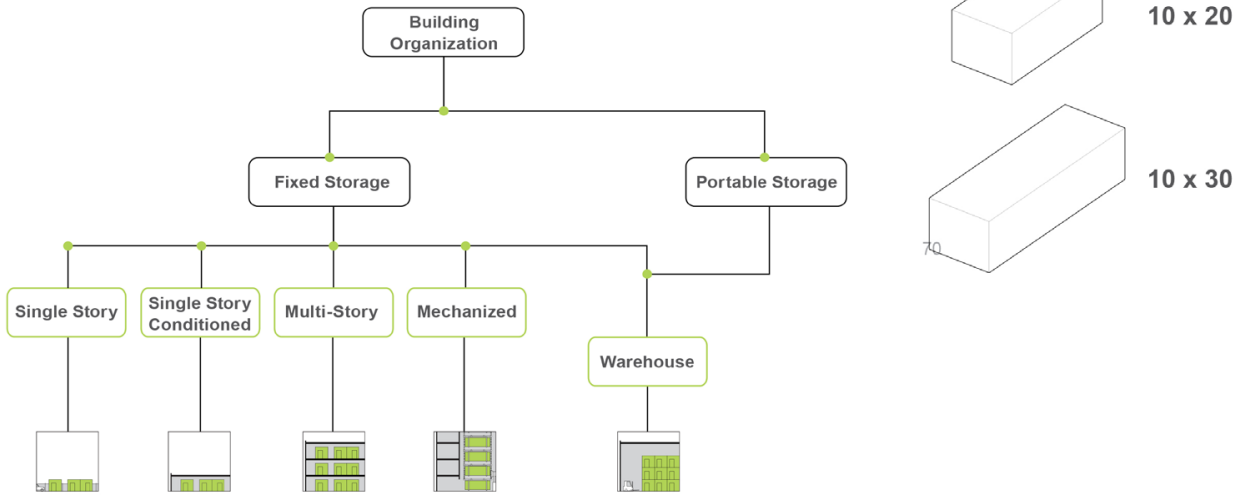

Room Comparison
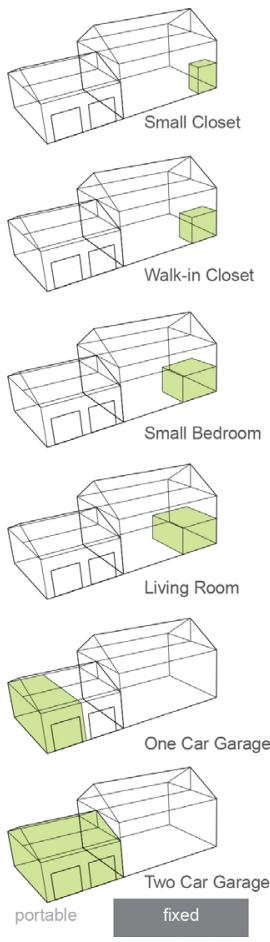
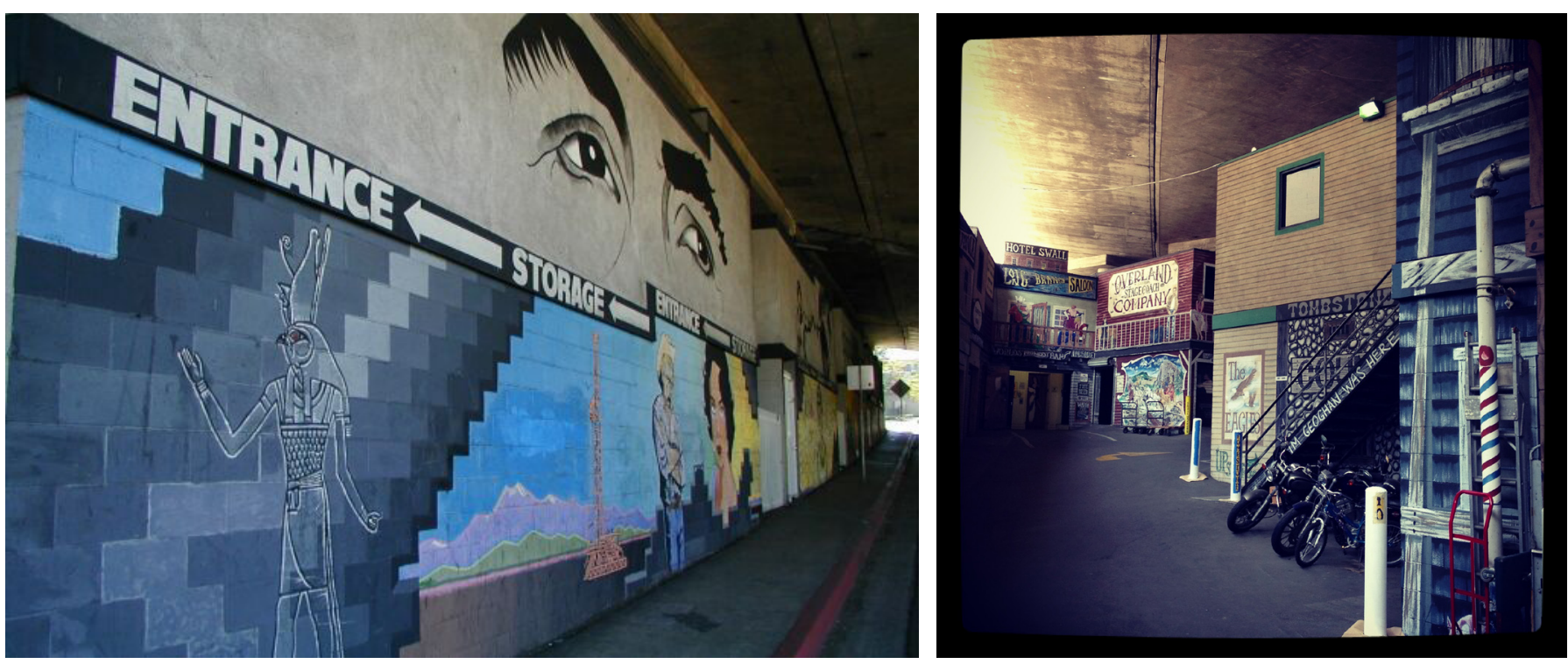

Clockwise from top. Figure 6: AA Valu U Stor Self Storage in Yuma, AZ. Self Storage Blog. Figure 7: Storage unit dimension and room comparison. Self Storage. Graduate Thesis. Northeastern University - School of Architecture. Figure 8,9: Hollywood Bowl Self Storage in Los Angeles. Figure 10: Typology for fixed and portable storage. Self Storage. Graduate Thesis. Northeastern University - School of Architecture. 
artist's murals; they even embraced green design in the form of solar panels, green roofs and urban farms.

According to the 2014-15 Self Storage Industry Fact Sheet, 52 percent of self-storage facilities in the US is located in suburban areas, 32 percent in urban areas and 16 percent in rural areas. The ideal self-storage location is found between or near dense multi-family residential areas and retail locations or located near a major artery. Historically, if a developer owned a lot of land not particularly suited for anything, the best use has been self storage. ${ }^{2}$ Sites zoned traditionally for self-storage have been under the warehouse or industrial parcel classification. Self-storage developers would only target those zones for new projects, but a lot has changed in recent years. Customers expect self-storage facilities that are conveniently located in commercial, retail and even residential areas. Therefore, storage developers must pursue rezoning. If self-storage is not permitted under a municipality's current zoning it must undergo special review and approval, as self-storage does not have "zoning by right." ${ }^{65}$ Some cities allow for self-storage in areas that are zoned for light industrial uses, while other municipalities view self-storage as retail. In addition, carve-outs and exclusions in certain zoning districts mean that an industrial zone could have restrictions on development of chemical plants, junkyards and self-storage facilities. While the industry has changed and embraced more sophistication, some cities might turn down a new storage facility in the correct zoning if they do not like the design. Thus the ease or difficulty in obtaining the green light for building a new storage facility varies on a case-by-case basis. ${ }^{66}$

\section{CONCLUSION}

This brief paper, part of a larger study, has sought to introduce the idea that the typology of the self-storage facility encompasses architectural, urban and planning issues and ties them to social and economic ones. Analyzing these relationships is essential to be able to understand the various reasons behind the rapid rise of self-storage in contemporary times. In its most common use, the residential one, self-storage is an identifiable architectural offspring of a lifestyle based on excess of possessions and inability to rid one's self of this excess. Self-storage is only useful for short-term, transitional periods. We understand that it is illogical to pay to keep something we already own, and likely pay more in rent that what our possessions are worth. Yet, packing extra stuff in windowless warrens has become more than a quirk -- it is part of the American lifestyle and we have accepted paying for it ${ }^{67}$. Dr. Roxanne Varzi, an anthropology professor at UC Irvine, sees far less need to own and keep in other cultures. The American psyche seems gripped by a constant, low-level fear about not having enough. One could say that the booming self-storage facility is proof of that scarcity mentality. Yet, storage facilities are not the problem, just as doctors who treat cancer aren't the problem. We must be careful not to not criminalize the symptoms: the need for so much off-site storage (and stuff) is the real disease. ${ }^{33}$

\section{ENDNOTES}

1. Mehrotra, Rahul, ed. "Everyday Urbanism: Margaret Crawford vs. Michael Speaks." Michigan Debates on Urbanism: Volume 1. The University of Michigan,2004.

2. Sonne, Christian. "Self-Storage Economics." The Appraisal Journal (2013).

3. "What is self-storage?" Steel Storage Construction. Web.

4. "An Introduction to Self Storage." Self-storage Association. Web.

5. "2015-16 Self-storage Industry Fact Sheet" Self-Storage Association. Web.

6. Pleven, Liam. "Need to Store That? Booming Self-Storage Industry Says No Problem." Wall Street Journal. Oct. 132015.

7. Harris, Alexander. "U.S. Self-Storage Industry Statistics." Sparefoot Storage Beat, 26 May 2015. Web.

8. Chart from"Self-storage Market Statistics" Steel Storage Construction. Web.

9. Que Pasa: Self-storagein Latin America. Inside Self Storage. Web.

10. John Brown, Martin.Too much Stuff! America's New Love Affair With Self Storage. Alternet.org, June 3, 2008

11. "World's Oldest Known Granaries Predate Agriculture." Science Daily, 22 October 2009, https://sciencedaily.com

12. "Well-preserved seeds found in 3000-year-old storage units". History. CulturalChina, history.cultural-china.com.

13. Five Little Known Facts About Storage. Self Storage Finders. Web.

14. "Self Storage- an Industry Much Older Than You Might Imagine." Storage Blog, 19 February 2013. www.yostorage.co.za

15. Wouters, I. and M. Mollaert. (2001) Assessing 19th century 'fireproof' buildings. Transactions on the Built Environment, 55.

16. "The History of Bekins: 125 Years of Expert Moving." Bekins,www.bekins.com

17. "Company History". Bekins Moving \&Storage Co., www.bekinsmovingandstorage. com

18. History of Self Storage. Performance Self-Storage Group. Web

19. The History of Self Storage. Mobileattic.net. Web.

20. Vanderbilt, Tom. Self-Storage Nation. Slate. July 18, 2005.Web.

21. The History of Self Storage. Uncle Bob's Self Storage. Web

22. "Weird and Extremely Interesting Facts Related to the Self Storage Industry". USselfstorage.com. 23 April, 2015

23. Mooallem, Jon. "The Self-Storage Self" The New York Times Magazine, Sept. 2 2006.

24. "A Brief History of Self-Storage". Sparefoot Blog. 18 January, 2013. Sparefoot.com

25. Rogers, Joshua. "How Humdrum Self-Storage Became The Hottest Way To Invest In Real Estate". Forbes. April 13, 2016. Forbes.com

26. 2011 Self-Storage Almanac. The Editors of Mini-Storage Messenger

27. "Self-storage Industry Key Facts." Strategic Storage Trust. strategicstoragetrust. com

28. Jameson, Marni. "Do you really need to rent that self-storage space?" The Orlando Sentinel, 4 February 2014, orlandosentinel.com.

29. "Performance by Property Sector/Subsector."REIT, reit.com.

30. "Why Invest in Self-Storage?" Steel Storage, steelstorage.net.

31. "Are Self-Storage REITs Taking Over the Self-Storage Landscape?" USSelfStorage, 3 November 2015, usselfstorage. com.

32. "The Golden Hoard." The Economist. 12 August 2012. Print.

33. "Benefits of Self Storage" Steel Storage, steelstorage.net.

34. Nickola, Dana. "Why Does Florida's Space Coast Lead the U.S. In Per Capita SelfStorage Space?" Self Storage, 7 August 2013, blog.selfstorage.com.

35. "Self-Storage Hits Record-Setting Stride". Mini-Storage Messenger. July 2016.

36. "Self-Storage Industry Demand Drivers." Strategic Storage Trust, Inc. Web.

37. Self-Storage Demand Study. 2013 Edition. Self-Storage Association.

38. Peter D. Hart Research Associates Inc., "The Baby Boomer Generation-How their retirement will affect the future of the self-storage industry," Self-storage Association, July 2007

39. Lusky, Mark. "Yet More Reasons Why Self-Storage Grows". Owners Self Storage, 27 August 2013, owners.selfstorage.com August 2013, owners.selfstorage.com.

40. Metcalf, Eric. "Hoarding: More Than Just a Mess." WebMD, webmd.com.

41. "Guess How Many U.S. Storage Facilities There Are - Infographic". Sparefoot, sparefoot.com

42. Jespersen, Elizabeth. "What Self-Storage Trends Say About The U.S Economy". 
Sparefoot, sparefoot.com

43. Karl Marx The Fetishism of the Commodity and Its Secret. 1867. The Consumer Society Reader. Edited by Juliet B Schor and Douglas B. Holt. The New Press, New York, 2000.

44. Hayden, D. (2004). A Field Guide to Sprawl. New York: W.W.Norton and Company. B. T. (2000). Why Consumption Matters. In E. b. Holt, Consumer Society Reader.

45. Tilford, B. T. (2000). Why Consumption Matters. In E. b. Holt, Consumer Society Reader.

46. Small is Beautiful: U.S. House Size, Resource Use, and the Environment

47. May, E. T. (1999). The Commodity Gap: Consumerism in the Modern Home. In E. B. B.Glickman, Consumer Society in American History : A Reader. Cornell University Press.

48. Evans, Robin. Translations from Drawing to Building and Other Essays. Architectural Association, 2003.

49. "BETCO Opens New Multi-Story Self Storage Design Center". Betco, 9 March 2016, betcoinc.com

50. Carroll, J. et al. (2009). Self Storage (Graduate Degree Project Studio). Northeastern University School of Architecture. Boston, MA.

51. "Architectural Design. "Steel Storage, steelstorage.net

52. Dallenbach, Jeff. (2013) Architectural Considerations in Self Storage. Texas Self Storage Association.March/April.

53. MacDonald, Jay. "Miami Architect Peter Blitstein Brings Elegant Design to SelfStorage." The Storage Facilitator, 3 November 2014, blog.selfstorage.com.

54. Wolf, Liz. "What You Need to Know About Self-Storage Zoning." The Storage Facilitator, 30 June 2015, blog.selfstorage.com

55. Mattson-Teig, Beth."Navigating Zoning Laws in the New Development Cycle." The Orange County Register, 9 November 2015. Blog.selfstorage.com.

56. Ferrell, Davis. "Self-Storage Industry Keeps on Keeping." The Orange County Register, 22 September 2014, ocregister.com. Economy"

57. "Defy Clutter Declutterfy". Self Storage. Selfstorage.org. 